\title{
Pátraic surnames in the Fiants and Patent Rolls of Ireland Part 1: a method of approach to mega-data, and a Mac Caisín case study
}

by Mike Fitzpatrick PhD $\underline{\underline{ }}$

Independent Scholar, Auckland 0604, New Zealand

Journal of the Fitzpatrick Clan Society 2021, 2, 66-92

\section{Abstract}

The fiants and patent rolls of Ireland are an extraordinary and largely untapped source of information. This article taps into this valuable source with a focus on interrogating Pátraicsurnames, i.e., Patrick, Fitzpatrick, Kilpatrick, Mac Giolla Phádraig and Ó Maol Phádraig, which document grants, leases, and pardons, etc., issued under the Great Seal of Ireland. The extant records of fiants are for the period 1521-1603, and the patent rolls 1514-1575 and 1603-1633, i.e., much of the reign of Henry VIII of England to the eighth year of Charles I of England.

Ireland's fiants and patent rolls provide mega-data on names, places, occupations, relationships, and more, and Pátraic-surname records uncover rich narratives from all over Éire. Yet, there is a tendency for the vastness of the records to overwhelm, so a systematic approach is required to extract the maximum value. This article provides a method for 'eating an elephant', and one key is having a secure temporal frame of reference via which associations, familial and otherwise, can be understood.

By way of example, the surname Mac Caisín begins this series of articles on Pátraic surnames in the Fiants and Patent Rolls of Ireland. The choice of Mac Caisín may appear strange at first, since it is not obviously a Pátraic surname. However, this article argues the case study of Mac Caisín provides a clear example of how an interrogation of the fiants, and patents reveal many instances where members of Pátraic families are recorded by other names, such as Mac William, Mac Edmund, Mac Flynn and, maybe, Mac Caisín.

Understanding such names in the fiants and patents requires a sound knowledge of context so they can be distinguished as surnames or patronymics. Still, even then, there is evidence that members of Pátraic families sometimes took other surnames due to, for example, fosterage or to 'mask' a clerical lineage.

This article seeks to answer questions about the Mac Caisín of Osraí (Ossory), who were unquestionably the close associates of the Fitzpatrick barons of Upper Ossory. Were the Mac Caisín either a lineage from an individual called Caisín (a name meaning curly-haired) Mac Giolla Phádraig, or a line out of fosterage, or of a 'surname-masked' clerical lineage; or, was there even any kinship bond?

\section{When to read this article}

To extract maximum benefit from this article, 'Mac Giolla Phádraig Clerics 1394-1534 AD, Part I' (Fitzpatrick, 2021) should be read before this one. 


\section{Names, styles, edits, historical records, DNA}

This article is written in the English language, but the people and places discussed are Irish. To acknowledge the primacy of Gaeilge (Gaelic) and to allow readers to be able to find locations on modern maps, place names are provided in modern Gaeilge using the most common spelling; for example, Cill Dalua (Killaloe), unless the place name is titular, for instance, the baron of Upper Ossory.

The rendition of personal names and by-names of people in the fiants and patents and other records referenced in this article requires consistency because they can be variability even for the same individual, with mixtures of Gaeilge and English forms being used and sometimes with spellings imaginatively conjured up via phonetics. The approach here is to use the most obvious and correctly spelt form of the personal name, be it Gaeilge or an English form, for the particular individual in question. For example, there may be a Tadhg Fitzpatrick of Ráth Sháráin (Rathsaran), and a different individual called Teige Fitzpatrick of Cluain Boireann (Clonburren); the choice of Tadhg or Teige comes down to which is used first, or most often, for the individual. Surnames are much less problematic, and preference is for standard a spelling, e.g., as determined and published by authorities such as Mac Lysaght (1985).

Quotations are italicised, and long or textually significant quotations are also indented. This article is a living work, i.e., it can, and most likely will, be edited by the authors who will retain all versions. Every effort has been made to consult all available records related to the period relevant to this article, and Y-DNA data is current to the publication date. Y-DNA dating estimates are probabilistic and should be considered \pm two generations, i.e., \pm approximately sixty years.

\section{Introduction}

On the first pass, the appearance of 'Morogh McCassyn, of Crovan' in fiant 897 of Elizabeth 1 in 1566 (HMSO, 1879) piques the curiosity. Along with Morogh is 'Thomas McCassyn, of Boulleduff' (later, in 1585, referred to as a surgeon), and 'John McCassyn, of Delge, surgeon' (also referred to as Shane). The three Mac Caisín appear among the list of those pardons granted by the Queen of England to Barnaby Fitzpatrick, baron of Upper Ossory, his sons, and his adherents. Morogh (i.e., Murchadh, or Morgan) appears to have much status - he arrives near the top of the list, preceded only by the five extant sons of Lord Barnaby: Barnaby, John, Florence, Donell, and Geoffrey. That the sons are probably listed in order of rank, and therefore age, reveals that John, the illegitimate son of Barnaby and Joan ny Cearbhaill, appears to have been born while Margaret Butler, mother to all four of John's half-brothers, was still living; that little morsel is a topic for another day (Fitzpatrick, in press) - what immediately intrigues and occupies here is the high-status of Morogh Mac Caisín (Mac Cashin).

Mac Lysaghght (1991) referred to the Mac Caisín of Osraí as a 'medical family', and not without good reason. In addition to the 1566 reference to John Mac Caisín's profession, there are several mentions of other Mac Caisín surgeons or physicians in the fiants and 
patents. Altogether eight different individuals are named as medics between 1566 and 1607, six of whom are associated with Fitzpatricks or Mac Giolla Phádraig in Osraí (HMSO, 1879; HMSO, 1880; HMSO, 1883). Aoibheannn Nic Dhonnchadha (2006) explains how the Mac Giolla Phádraig Osraí were patrons of 'The medical school of Aghmacart' and her review leaves no doubt the Mac Caisín of Osraí produced a successive line of medics. Some may even have held the sought-after title of 'Chief Master of Medicine of Mac Giolla Phádraig', which could explain the appearance of Thomas and John above a slew of Fitzpatrick kin. Yet Morogh was never called a medic, which leads to the need to understand how he seemingly enjoyed high status in the clan. Of note is that other non-medics immediately follow Morogh in the fiant - the 'McSheare', 'McWilliam', 'McFynyne', and on they go. So, also - who are these people, and what of their status?

This article is the first of a multi-part series, which reviews the occurrences of the surnames Patrick, Fitzpatrick, Kilpatrick Mac Giolla Phádraig and Ó Maol Phádraig (subsequently, when a collective, referred to as Pátraic-surnames) in the fifteenth and sixteenth-century fiants and patent rolls of Ireland, that attempts to address the 'who are you?' question and others that arise from it, such as 'what were your origins' and 'who are your descendants today?' The task is enormous, and once one begins to work with the fiants and patents there come many 'going off on a tangent' moments, which enable the researcher to uncover essential elements of Pátraic-clan histories that would not have been discoverable by a linear approach. The fiants and patents contain several hundred references to Pátraic surnames, and at times it seems like anyone and everyone bearing a Pátraic surname makes an appearance.

But it's not just the names; it is the places, are all over Éire that also provide bright rays of hope for Fitzpatrick family historians who have hit an origins brick wall in townlands distant from Osraí, where Fitzpatrick origins were all said to lie. The narrative that all Fitzpatricks must have common paternal ancestry in Osraí (Shearman, 1879; Woulfe, 1923) is dead and buried (Fitzpatrick \& Fitzpatrick, 2020), but the resources this series of articles provides for Fitzpatricks, of many diverse origins, will endure.

\section{The fiants and patent rolls of Ireland}

To say the fiants and patents are a rich source of information for researchers of Pátraic surnames in Éire does no justice - they are remarkable in terms of the sheer number of records, and the combined extractable knowledge of locations, temporalities, family associations, occupations, and the like, is a gift that keeps on giving. Equally remarkable, and testimony to no small degree of dereliction is that those long considered the great scholars of Fitzpatrick histories - Shearman (1878), and Carrigan (1905) - grant the fiants and patents scant, if any, attention. It is little wonder, therefore, that Pátraic-clan histories have been turned on their head in recent times by a series of articles that combine Y-DNA analysis with records from the fourteenth to seventeenth centuries, which have previously barely seen the light of day (Fitzpatrick, 2021; Fitzpatrick \& Fitzpatrick, 2021). Even so, to date, the fiants and patents have barely featured as part of the wholesale revision of the faulty, pre-2020, Pátraic surname narratives.

C Copyright 2020-21 | All rights reserved | The Fitzpatrick Clan Society

Fitzpatrick, M (2021) Pátraic surnames in the Fiants and Patent Rolls of Ireland: Part 1: a method of approach to mega-data, and a Mac Caisín case study. The Journal of the Fitzpatrick Clan Society 2, 66-92. 
Given such a grand introduction, the fiants and patents require some explanation. What are these records, and why do they matter so much? Writing in the preface to Volume One of his 'Calendar of Patent and Close Rolls of Chancery in Ireland', James Morrin, who was clerk of enrolments at the Chancery, described the records of Ireland, lamenting that there was:

'not a perfect series of records, from the commencement in this country of the English Government: occasioned by the decay of time; by the negligence of officers; by the insecurity in which they were kept; and by casualties from fire' (Morrin, 1861, p.xi).

Irish state records had previously been described as poorly kept. In 1760, the Deputy Keeper of Rolls noted they were 'in a very ruinous condition'. This concern became the focus of an 1810 Irish Record Commission 'issued for the better regulation of records in Ireland'. Action ensued, and by 1815 the Commission had published the first of a series of reports providing inventories from the various records offices and the condition of the records kept therein. The publication of records themselves, such as part of the first volume of Patent Rolls from Henry II to Henry VII, soon followed; however, in 1830, the Irish Record Commission was suspended (Morrin, 1861).

Morrin described the various records removed to his place of employ, at Four Courts, including the fiants, which he generally considered of somewhat lesser importance because they only served as the legal documents to direct Letters Patent to be passed. Morrin noted the fiants were 'preserved in large bundles' and were largely unindexed but, prophetically, were of value 'considering that if accident happen to any of the patent rolls, they can be replaced, in a great measure, by the fiants' (Morrin, 1861, p.xxxiv). The fiants, being records of Letters Patent, are so known from the initial words from the original legal documents 'Fiant literæ patentes' (HMSO, 1875, p.11), which means 'let the letters patent be' - and are now considered of great value because they are the primary record with authority of grants, leases, and pardons, etc., issued under the Great Seal of Ireland. And the fiants may also be considered superior to the actual Letters Patent because although fiants 'were all supposed to be enrolled ... numerous instances occur where the patent' is not found (Morrin, 1861, p.xxxiii). Hence, the fiants provide more information than found on the patent rolls.

As Morrin feared, the original fiants and patent rolls were destroyed in the Four Courts explosion and fire (Fewer, 2019). However, late nineteenth-century copies of many fiants are contained in a series of reports of the Deputy Keeper of Public Records in Ireland, commencing with the seventh report (reign of Henry VIII, 1521-1547) published in 1875, and ending with the eighteenth report (reign of Elizabeth I, 1601-1603) published in 1886. Patent rolls have been published in various formats, most notably in Morrin (1861), which covers the period of a continuous portion of the reigns of Henry VIII, Edward VI, Mary I and Elizabeth I (1514-1575), 'The Calendar of the Patent Rolls of the Reign of James I' (Clarke, 1967) which covers the entirety of James' reign (1603-1625), and 'The Calendar of the Patent and Close Rolls. Chancery, Ireland, of the Reign of King Charles I' (Morrin, 1863), which covers the first eight years of Charles' reign (1625-1633). 
It is easy to become lost amongst the many hundreds of references to individuals with Pátraic surnames in the fiants and patents. There is a need for robust methodology if sense is to be gained of both individuals and the collective. As with the proverbial, 'how to eat an elephant', the first bite of many must be taken, but starting at the beginning of the fiants (1521 AD) or patents (1514 AD) is not the chosen approach for this work. Instead, the year 1566 AD serves as a crucial temporal frame of reference for understanding the contexts of family networks and political associations. And it is the surname Mac Caisín that will first illustrate the methodology employed here because, once an historical frame of reference is secured, the Mac Caisín demonstrate the value of making connections between surnames, places of abode, occupations, and the like.

Numerous questions come as the fiants and patents are examined, for example - if the Mac Caisín were medics and, otherwise, close associates of the Mac Giolla Phádraig Osraí, were they also kin in some way and, if so, where did they originate? Could the Mac Caisín have emerged as a patrilineal Mac Giolla Phádraig Osraí sept who, perhaps, adopted a distinctive patronym from an individual called Caisín Mac Giolla Phádraig? And may have some Mac Caisín reverted to the surname Fitzpatrick at a later stage? These are just the beginning of the questions and the uncovering of Pátraic-surname mysteries hidden in the fiants and patent rolls of Ireland.

Once the patents and fiants yield information of interest, other records become more readily understood, and more mindfully accessible. In addition to the fiants and patents, other invaluable sources of land records can be used for purposes of correlation and expansion of narratives, most notably from 'Inquisitionum in Officio Rotulorum Cancellarie Hiberniae Asservatrum Repertorium'. These are the records of inquisitions in the Rolls Office of the Court Chancery of Ireland, classified as either inquisitions post mortem or inquisitions on attainder. The inquisitions post mortem provide the legal account of

'what lands any person died seized of, by what rents and services they were held, and who was the next heir and his age ... all grants of wardships of body and marriage liveries of lands - pardons of intrusion - pardons and licences of alienation, etc. in virtue of the tenures in capite. They are the best evidences of the descent of families, and of the transfer and possession of property during the period they embrace. Numerous family settlements, deeds, wills, leases, and other Instruments relating to property in Ireland, are set out at full, or copiously recited; and of the greater number of these there are, at present, no other traces to be found' (Inquisitionum in officio rotulorum cancellariae Hiberniae (IORCH), 1826, p.ix).

The inquisitions on attainder show,

'whether any person was attainted, in which case his lands and other property, which were also found, were seized into the King's hands' (IORCH, 1826, p.ix).

Once sufficient information is extracted from the combined sources, it becomes a matter of trying to draw out a narrative. The method employed in this article explores individuals and

(C) Copyright 2020-21 | All rights reserved | The Fitzpatrick Clan Society

Fitzpatrick, M (2021) Pátraic surnames in the Fiants and Patent Rolls of Ireland: Part 1: a method of approach to mega-data, and a Mac Caisín case study. The Journal of the Fitzpatrick Clan Society 2, 66-92. 
their relationships via an understanding of historical events in time and place, and essential is establishing key points of reference.

\section{$1566 \mathrm{AD}$, and other key points of reference}

Close your eyes and imagine beyond the eighteenth-century Fitzpatrick genealogy brick wall. In this world, you can see a head of a family, his sons and grandsons, his brothers and their sons, his uncles, and their sons - it could almost be a 'male side' family reunion.

Connections can be made in a never-before-elucidated way via naming patterns and where the extended family members lived. And the men are all together on a fixed date as if it were a coming together for a medieval family photograph. The date is 30 June 1566, and it is one of several that afford a key point of reference for a high-level understanding of the kin connections of Barnaby Fitzpatrick, first Baron of Upper Ossory. Although they were by no means the only Pátraic-clan in Éire during the period when the fiants and patents are available, Barnaby's acquisition of large landholdings in Laois in 1541 (State Papers, 1834) means he and his descendants were often 'part of the action' in the Irish midlands during the sixteenth and seventeenth centuries. As will be seen in subsequent articles, it is possible to reconstruct Pátraic-clans, particularly from Bréifne, Laighean, Mumhan, from the fiants and patents, and how they were aligned concerning political affairs of the day - although none to the same depth as the heavily documented Fitzpatricks of Osraí.

Points of reference are key to the methodologies employed in this series of articles because they are timestamps for when dumps of mega-data occurred, which can be held on to with great confidence - confidence underpinned by the Great Seal of Ireland. One such point of reference is 30 June 1566, although that was a day of forgiveness. The event that led to the need for absolution from Elizabeth I was 8 February 1565 - the triod mhór was the Battle of Áth Mheáin (Affane), and there were Fitzpatricks on one side and Mac Giolla Phádraig on the other. Áth Mheáin is referred to as 'the last private battle fought between noblemen in Ireland', between Thomas Butler, tenth Earl of Ormond, and Gerald FitzGerald, fourteenth Earl of Desmond; the outcome was a decisive victor for Ormond (Connolly, 2011), but neither party escaped Elizabeth's fury. The Calendar of the State Papers of Ireland record Elizabeth's letter to 'the Earl of Ormond and Ossory... [and her] ... mislike of the meeting in such manner of hostility between him and the Earl of Desmond' (Hamilton, 1860, p.253).

Fiant 897 of Elizabeth I demonstrates Barnaby Fitzpatrick, and many of his kin, sided with Ormond, and yet not one is referred to as Mac Giolla Phádraig (Twemlow, 1921), that name surrendered as part of the conditions of submission to Henry VIII, being that Barnaby 'doth utterly forsake and refuse the name of MacGilpatricke' (State Papers, 1834, p.291). On the side of Desmond were the Caomhánach (Kavanagh) and one of the heads of those supporting the fourteenth Earl, who was pardoned in relation to the conflict, was Gerald mac Cahir Caomhánach (HMSO, 1879). Gerald's father, Cahir Caomhánach chief of his sept, had married Cecilia, the daughter of Gerald FitzGerald, ninth Earl of Kildare and, at the time of Áth Mheáin, the relationship between the Earl of Desmond, the Earl of Kildare, and the Caomhánach was close. Among those Caomhánach followers granted pardon were Gerald Mac Giolla Phádraig, Ferdinand ruadh Mac Giolla Phádraig, and Símon ruadh Mac Giolla Phádraig. Gerald, Ferdinand, and Simon feature in several other patents, before and after 
1566, variously domiciled in a tight area triangulated by southwest Cill Dara (Kildare), western Ceatharlach (Carlow), and southwest Cill Mhantáin (Wicklow). The question, 'who are these Laighin Mac Giolla Phádraig?', will be addressed in subsequent articles (Fitzpatrick, in press).

Apart from 1566 and the aforementioned surrender and regrant relating to Barnaby Fitzpatrick, other vital dates when large numbers of Pátraic surname entries appear in the fiants and patents are as follows: 1571, relating to the Butler revolt (Edwards, 1993); 1576, relating to the rebellion of Ruairí Óg Ó Mórdha (Rowe, 1916); 1581, following the death of Barnaby Fitzpatrick, second Baron of Upper Ossory (Carrigan 1905); from 1597-1604, many entries relating to the Nine Year's War (Morgan, 1993); and, 1619, relating to plantations in Cill Mhantáin (Price, 1933). These events, along with 1566, provide the critical contexts for where Pátraic surname connections and broader alliances lay. And it is the abodes, alliances, occupations, and origins of one such family of allies, the Mac Caisín, that occupies much of the remainder of this article.

In addition, with respect to 1566 and related fiants, Owen mac Owen Mac Caisín, surgeon, of An Ghráinseach, Cill Chainnigh (Grange, Kilkenny) was named in a list of pardons granted to supporters of Thomas Butler, tenth Earl of Ormond (HMSO, 1879). And in 1571, Hugh mac Owen Mac Caisín, physician, of Cill Chainnigh, was pardoned along with Butler associates (HMSO, 1880). These two medical sons of Owen Mac Caisín are of a lineage with as yet unknown associations with the Fitzpatrick barons of Upper Ossory.

\section{The Mac Caisín in the fiants and patent rolls of Ireland}

As will be observed throughout this series of articles, the accurate interpretation of placenames as they appear in the fiants and patents is of no minor consequence and no mean feat of achievement. It is fortunate that scholars who have written about Osraí, particularly Carrigan (1905), had an intimate understanding of its places, coupled with a fluency of Gaeilge and an ear for phonetic spellings of Irish placenames in English. And researchers are also able to draw on the resource that is the Placenames Database of Ireland (https://www.logainm.ie). Hence, the Mac Caisín places of abode in 1566 can be understood: Crovan is Cruail (Cruell); Boulleduff is An Baile Dubh (Ballyduff); and, Delge is Cill Deilge (Kildellig). So, what can be learnt of these townlands that could enrich the narratives of the Mac Caisín occupants? This is where other records can come into play.

There are further supportive resources, such as the important Kildare Rental, which identify various Mac Giolla Phádraig townlands before the 1543 grant to Barnaby Fitzpatrick (MS Harleian 3756; Hore 1859; Hore, 1862; Hore, 1866; Mac Niocaill, 1992). Cruail is mentioned therein as a part of 'McGyllepatrickis countre', which would become the abode of Morgan Mac Caisín, but which in 1518 was subject to Gerald FitzGerald, ninth Earl of Kildare, notably by Clann Maeleachlainn Ruadh. Cruail was also a townland of some contention concerning the 1571 grant of lands by Barnaby Fitzpatrick to Thomas Butler, tenth Earl of Ormond; that grant in feoffment to Butler included many various manors, lordships, and castles, etc., but made specific mention that Cruail and the neighbouring Baile Uí Ghaoithín (Ballygeehan) 
and Cloch Choill (Knockkyle, or Springfield), were provided to John Fitzpatrick, his son - here the Ormond Deeds are the source (Curtis, 1941).

Fiant 6733 of Elizabeth I, in 1602, records a long list of Fitzpatricks of Osraí headed by Teige, the son of Florence, third Baron of Upper Ossory, who were pardoned following their support of Hugh Ó Néill. Here Fynyn mac Donell Fitzpatrick is recorded as from Cruail (HMSO, 1885). This Fynyn was the son of Donell (the son of Barnaby Fitzpatrick, first Baron) of Gort na Cleithe (Gortnaclea), which is but one mile north of Cruail, but no familial relationship between Donell and the Mac Caisín can be established. And a 1607 fiant from the reign of James I records the (ultimately failed) suit of Teige Fitzpatrick, the son of the John Fitzpatrick, brought against his uncle, Florence Fitzpatrick, the third Baron, in part for Cruail (Clarke, 1967), but the rationale behind why Teige claimed the townland is not discoverable. Cruail was adjudged to Florence, and after his demise it passed to his son John, a younger brother of Teige, the fourth Baron (Curtis, 1970). Hence it appears clear that after 1543, at least, Cruail was held by Barnaby Fitzpatrick, the first Baron, and then his descendants, and remained that way until 1659, or later (Pender, 1939). The circumstances around Morogh Mac Caisín dwelling there in 1566 have not been discoverable, but it was not because of possession; more likely it simply because it was a secure abode, that being the strong castle of Cruail-Baile Uí Ghaoithin (Cruell-Ballygeehan) (Down Survey, 1641; Carrigan, 1905).

An Baile Dubh in the parish of An Chill (Kyle; in ancient times called Cill Cluain Fearta Molua, i.e., possibly the church of the 'wondrous resting place' of Molua), which is in the diocese of Cill Dalua, not in the diocese of Osraí as one might expect based on location. When St Molua was near death ca. 609 AD, he left his termon lands to St Crónán of Ros Cré (Roscrea). The ancient coarbs of An Chill were the Uí Duigin (O'Deegan) of Cluain Cuas (Clonecourse) (Gleeson, 1949; Gwynn \& Gleeson, 1962), which provides the context for several entries recorded in Papal records: in 1400, the rectory of An Chill was noted as void on the death of Donát Ó Duigin (Bliss \& Twemlow, 1904a); in 1418 Thady Ó Duigin was rector (Twemlow, 1906); and, in 1479 William Ó Duigin was assigned the rectory (Twemlow, 1955; Gleeson \& Costello, 1943). The clerical appointments to the rectory of An Chill are consistent with the possession of An Baile Dubh being with the Uí Duigin, and the townland does not appear to have passed to Barnaby Fitzpatrick in the grant of 1543.

Fiant 6551 from the reign of Elizabeth I records the 1601 pardon of William Ó Duigin, 'of Kilballeduff, husbandman' (HMSO, 1885), and an inquisition of 1613 found William held An Baile Dubh 'sed quo jure, preter antiquā possesione' (by what right, apart from ancient possession) (IORCH, 1826). An Baile Dubh, comprising '631 acres arable, and 1340 acres bog', went to Philip Ó Duigin, probably William's son, in 1629 (Morin, 1863) - Philip died that year, and an inquisition post mortem in 1631 recorded the proprietorship passed to his son John, aged twenty-four years (IORCH, 1826). John Ó Duigin was killed in the 1641 rebellion (Cooke, 1852), and the Down Survey terrier records he held An Baile Dubh at that time (Down Survey, 1641). The circumstances around Thomas Mac Caisín dwelling among Ó Duigin at An Baile Dubh in 1566 have not been discoverable but, as with Cruail-Baile Uí Ghaoithin, there was a castle, known as Cluain Cuas, which existed there from at least 1622

(C) Copyright 2020-21 | All rights reserved | The Fitzpatrick Clan Society

Fitzpatrick, M (2021) Pátraic surnames in the Fiants and Patent Rolls of Ireland: Part 1: a method of approach to mega-data, and a Mac Caisín case study. The Journal of the Fitzpatrick Clan Society 2, 66-92.

doi:10.48151/fitzpatrickclansociety00621, Ver1, 30 October 2021 
(Down Survey, 1641; Nelligan \& Dempsey, 2020), which is an indication of an earlier secure place of dwelling.

Cill Deilge, meaning church of the thorns/thorn trees, features in several medieval records. In 1267 it was the possession of one of several Norman families (Curtis, 1932) and next finds mention in 1425 when the 'church of Delge', of lay patronage, was provided, along with the rectory of Ráth Sháráin, to a scholar called Diarmaid Ó Brain (O'Byrne) who was the son of an Augustinian cleric (Twemlow, 1906). Evidence for Uí Brain succession at Cill Deilge is clear from the 1480 appointment of Thady Ó Brain, a son of a priest, following Donát's Ó Brain's seven to eight-year possession, which was without canonical right (Twemlow, 1955). Thady's appointment was subject to challenge in 1484 by John Ó Duigan with the resolution being unknown, and by 1491 the benefice of the Rectory of Cill Deilge has devolved to Rome, having been detained illegally by another Ó Duigan, Patrick. A Mac Giolla Phádraig interest in Cill Deilge is apparent in 1493 with the appointment of Patrick Mac Giolla Phádraig to the rectory (Fuller, 1986; Clohosey, 1957), but by 1525 it had returned to the Uí Duigan (Mac Quarrie, 2018).

Hence, there is no evidence of hereditary Mac Giolla Phádraig possession and patronage at Cill Deilge; instead, it is the Uí Duigin who dominated clerical appointments in the late fifteenth and early sixteenth centuries. The proprietorship of Cill Deilge, as with An Baile Dubh, probably came to John Mac Caisín by virtue of a relationship between the Mac Caisín and the Uí Duigan. However, it is not impossible that Cill Deilge wrested from the Uí Duigan and provided to John Mac Caisín by Barnaby Fitzpatrick after large swathes of lands, much not hereditary, came into Barnaby's possession in 1543, for two knight's fees and an annual rent of $£ 313 \mathrm{~s} 4 \mathrm{~d}$ (State Papers, 1834), on confirmation of the patent grant of the Barony of Upper Ossory made on 11 June 1541 (Morrin, 1861; HMSO, 1875).

It is unlikely no coincidence that the rise of Barnaby Fitzpatrick came on the back of the rise in power of the Mac Giolla Phádraig clerics from the late fifteenth century. Deciphering the relationships between the Mac Caisín, the Uí Duigan, and the Mac Giolla Phádraig of Osraí, and other familiarly connected residents such as the Costagáin (Costigan, or Mac Costigan), cannot be achieved in isolation from church records and an appreciation of just how interwoven some clerical lineages were (Nicholls, 1970; MacCotter, 2004; Mclnerney, 2014; Fitzpatrick, 2021). And, in this regard, it is not useful to maintain a generalistic and monocular view that the Mac Caisín of Osraí were simply a 'medical lineage' - they were not solely that, and this aspect will be discussed further in the next section.

But returning to Cill Deilge, fiant 6551 from 1601 records Teige (also known as Thomas) Mac Caisín, 'of Killdelgen' (HMSO, 1885), who is one of eleven Mac Caisín associates of Florence Fitzpatrick (the third Baron) who received pardons; among the eleven was also Gilpatrick mac Shane, a surgeon who had followed his father's, i.e., John Mac Caisín's, career path. In 1605, following the death of Teige Mac Caisín, Florence, granted Cill Deilge to Donogh and Conly (i.e., Connghalaigh), who was a husbandman, Mac Caisín, and their brothers (IORCH, 1826). As will be discussed in the next section, in 1607 a Mac Caisín was not the chief Master of Medicine for the Fitzpatrick barons of Upper Ossory, although the role of some Mac Caisín as medics continued. Patrick Ó Caisín, a surgeon, of Cill Deilge-Baile Raighleáin 
(Kildellig-Ballyreilly) was among those pardoned among the retinue of Shane mac Teige Mac Giolla Phádraig and Donnogh mac Teige Mac Giolla Phádraig (Clarke, 1967); it appears that while they did not service the barons, the Mac Caisín medics did have a medical role among the Mac Giolla Phádraig 'rebels'.

A 1613 inquisition found William Mac Caisín, Owen Mac Caisín, Donogh Mac Caisín, and Patrick Mac Caisín in possession of Cill Deilge (IORCH, 1826), but by 1618 it was solely with Owen, granted him by Barnaby Fitzpatrick, son of Teige the fourth Baron, who was residing at Caisleán an Uisce (Watercastle) (IORCH, 1826). Owen was indicted and outlawed in 1621 (IORCH, 1826; Clarke, 1967), and William Mac Caisín, perhaps Owen's brother, then alleged the right to the title. But by in 1629 Cill Deilge was back with Owen - Charles I regranted him ' 213 acres arable ... in the territory of Upper Ossory' (Morrin, 1863), which was only a portion of the townland since large parts of Cill Deilge and Baile Raighleáin were included in a swathe of lands, some '3785 acres bog, wood and mountain', granted to George Villiers, the Duke of Buckingham, in 1624 (Clarke, 1967). By 1659 there was no longer evidence of a Mac Caisín presence in Cill Deilge - the proprietor was John Petit, alias John Short. Yet, between when they first appeared in the fiants in 1566 and the time of the ad hoc 1659 'Census', the Mac Caisín of Osraí were not diminished. And it is possible to connect many of the Mac Caisin in the fiants and patents with those recorded in 1659 and construct some of their lineages by virtue of another vital point of reference - the 1641 rebellion.

\section{The Mac Caisín of Osraí in 1641}

The circumstances and events surrounding the 'Irish rebellion' of 1641 have been exhaustively reviewed via modern lenses in recent works such as 'Tyrone's Rebellion' (Morgan, 1993), 'England and the 1641 Irish Rebellion' (Cope, 2009), 'The 1641 Depositions and the Irish Rebellion' (Darcy, Margey \& Murphy, 2016), 'The Shadow of a Year' (Gibney, 2013), and 'The Irish Rebellion of 1641 and the Wars of the Three Kingdoms' (Darcy, 2015). 1641 brings other records into play, and the depositions are considered among the most important documents of Irish history; they are witness testimonies, mostly from protestants, relating to first-hand accounts of the rebellion - almost 20,000 pages of depositions are held at Trinity College, Dublin, but they are also available online at http://www.1641.tcd.ie.

Before the outbreak of the 1641 hostilities, Morgan Mac Caisín, referred to by Carrigan (1905) as 'the principal man of his name', was in possession of several townlands in Laois. $\mathrm{He}$ is mentioned in two depositions and the accounts of English army officers, where he is referred to as a gentleman and a Justice of the Peace. Morgan Mac Caisín, of An Corrán (Corraun), his eldest son, Captain John Mac Caisín, and Patrick Mac Caisín were among 'the chief of the rebels that were slain'. Morgan's second son, also Morgan and a gentleman, is stated as being in rebellion, but he was not killed (Bacon, 1642; 1641 Depositions). In addition to An Corrán, in 1641, either Morgan Mac Caisín or his namesake son were in possession of several other townlands in Achadh Bhó: An Cheathrú Riabhach (Carrowreagh); Garraí an Uisce (Garryniska); Cúlbhaile (Coolbally); Baile Uí Ghamhdáin (Ballygowden); and the moiety of An Srath (Srah). In 1659 Morgan, junior, held the title of Conc an Fhalmairigh (Palmershill) (Pender, 1939). 
Prior to 1641, Cúlbhaile was held by Edmund Óg Mac Giolla Phádraig in 1566 (HMSO, 1879), Donell mac Murtagh Mac Caisín, gent, in 1601, 1605, and 1613 (HMSO, 1885; Clarke, 1967; IORCH, 1826). Before 1641 Baile Uí Ghamhdáin was in the possession of Anya Ní Costigan (HMSO, 1885), and Thady mac Donell mac Donnogh Mac Giolla Phádraig and Kellagh mac Teige Mac Giolla Phádraig held it in 1613 (IORCH, 1826). In 1601, the moiety of An Srath (Srah) was with the surgeon, and the official physician to Mac Giolla Phádraig, Donnchadh Óg' Ó Conchubhair (HMSO, 1884). These various records evidence that lands within a general area between just north of Achadh Bhó and just south of Ráth Domhnaigh (Rathdowney) were associated with lesser ranked kin and followers of the barons of Upper Ossory (Figure 2). Similarly, Morgan Mac Caisín's 1641 lands in the parishes of Cúil Choire (Coolkerry), Bordaíol (Bordwell), and Ráth Domhnaigh provide evidence that the Mac Caisín were domiciled in, or near Ráth Domhnaigh town. Most notable in the parish of Ráth Domhnaigh are Morgan Mac Caisín's occupancies of Ráth an Phiobaraigh (Rathpiper) - a castle was there where Shane Mac Caisín dwelt in 1601 (HMSO, 1885) - and Áth Cip (Akip), where Dr Conly Cashin gentleman held the title in 1659 (Pender, 1939).

Apart from Morgan's holdings in 1641, the Down survey terrier and map for the parishes of Cill Baile Dubh (Kilballyduff) and Uí Fhairchealláin (Offerlane) show John Mac Caisín and Edmund Fitzpatrick held 298 acres in An Lóthrán (Lowran) and Doirín Oilibhéir (Derrinoliver). That a Fitzpatrick and a Mac Caisín shared An Lóthrán ca. 1641 echoes that found in a 1613 inquisition post mortem into the holdings of Florence Fitzpatrick, the third Baron, when Thady McFynyn and Morgan Cashin held An Lóthrán by virtue of ancient possession (IORCH, 1826) - residence almost 100 years previously, in 1518 was with Clann Maeleachlainn Ruadh (Mac Niocaill, 1992). The sequence of tenure at An Lóthrán provides a clear example of what this series of articles will repeatedly demonstrate, viz., the Mac Giolla Phádraig are oft-recorded in the fiants and patents by a patronym, not a surname, thus making the records a treasure trove of undiscovered Mac Giolla Phádraig individuals and lineages. In this case, it is the appearance of Tadhg mac Fynyn who leads to the questions, 'who was Fynyn Mac Giolla Phádraig?' and 'what was his relationship to (a) Edmund Fitzpatrick and (b) Clann Maeleachlainn Ruadh?', because those two individuals, and an entire sept, have gone largely undiscovered - it is a journey through fiants and patents that makes such discoveries commonplace.

Another Mac Caisín to feature in the Down survey is Anthony, who is recorded as holding Cnoc an Mhuilinn (Knockamullin) and An Chrois (Cross), in the parish of Achadh Bhó (Aghaboe) (Down Survey, 1641). Cnoc an Mhuilinn was previously held by Hugh Mac Caisín in the early seventeenth century, but he was attained in 1611, and the townland passed to Gerald FitzGerald, fourteenth Earl of Kildare (IORCH, 1826; James, p.316. After Kildare's death, the townland returned to the Mac Caisín (Owen). Anthony is also recorded in the 1641 depositions as being in rebellion (1641 Depositions). There are several other Mac Caisín who find little reference in the fiants, patents, and depositions. Still, they contribute to an understanding of the wider Mac Caisín lines in the seventeenth century, and some are also identified by location. In 1601 Gilpatrick mac Shane Mac Caisín, surgeon, Conly Mac Caisín, husbandman, and the aforementioned Hugh Mac Caisín were dwelling in Doirín na Saileach (Derrin) along with Fynyn and Shane mac Donell (HMSO, 1885) - the latter pair were Mac Giollo Phádraig descendants who had been identified by patronymic. In 1602 
Gilpatrick mac Shane is recorded as dwelling at Baile Uí Bróithe (Ballybrophy), and as well as being a surgeon, he is referred to as a yeoman; his cousin, Morgan mac Hugh Mac Caisín, is similarly described and was living at Cluain Boireann (HMSO, 1885), which was the stronghold of Teige Fitzpatrick (Clarke, 1967), who would become the fourth Baron in 1613. Such richness of information from the fiants, patents, and other sources affords the development of a proposed pedigree of Mac Caisín medics of Osraí, which is provided in Figure 1. Figure 2 illustrates the townlands associated with the family from 1566-1641. Following the events of 1642, the Mac Caisín yet remained a principal family in Osraí. The 1659 'Census' records twenty-four adult men living in the Barony of Ossory and eight living in the Barony of Maryborough (Pender, 1939).

\section{The origins of the Mac Caisín of Osraí}

It has been demonstrated with certainty that the Mac Caisín of Osraí were a 'medical family' (Nic Dhonnchadha (2006). Eight distinct Mac Caisín medics are referenced in the fiants and patents between 1566 and 1607, and six were resident in Osraí across three generations. Yet, any suggestion that Mac Caisín were a medical lineage of Osraí from more ancient times is presumptuous - there is simply no record before 1566.

Ó Muráile (2016) provides a thorough treatise entitled 'The Hereditary Medical Families of Gaelic Ireland' in which he explains that hereditary learnèd families, which first arose in the thirteenth century,

'furnished poets, others historians, others lawyers, others scribes, yet others medical practitioners, while a number of them could be deemed to have been multidisciplinary' (Ó Muráile, 2016, p.85).

Here, then, lies a clue to where Mac Caisín origins can be found. Medical science in medieval Éire cannot be understood without a consideration of where sources of knowledge lay. Early medieval monasteries in Éire were centres of learning of unquestionable importance, and while 'not comparable to the great [early] Christian schools of Antioch and Alexandria' neither were they 'purely ecclesiastical seminaries where the merest rudiments of theology were taught and where profane learning was either feared or despised' (Graham, 1925, p.431). The long tradition of learning at monastic centres in Éire was not diminished after the Norman invasions and the 'Hippocratic corpus', which 'formed the basis of advanced teaching of medicine throughout Europe' from the twelfth to the sixteenth century soon made its way to Éire. The first translations from Latin into Irish, was by Mumhan medical scholars and scribes, Aonghus Ó Callanáin and Niocól Ó hlceadha, and date from 1403. Another well-known early medic, herbalist, and scribe was Tadhg Ó Cuinn, a 'bachelor of medicine' (Nic Dhonnchadha, 2000).

Yet earlier references to those Irish so conferred with degrees of medicine can be found. It is of little surprise within the context of monastic scholarship that the Papal Registers record, in 1390, 'the extension of successive dispensations on account of illegitimacy' was made to Malachy Ó híomhair (O'Howard) of the diocese of Cill Dalua, a 'bachelor of medicine', and the archdeacon of Cill Fhionnúrach (Kilfenora). Malachy was permitted to 
hold up to three benefices and was even allowed to 'exchange them as often as seems good to him for similar or dissimilar mutually compatible benefices' (Bliss \& Twemlow, 1902). Gwynn and Gleeson (1962) chose not to categorise individuals of great knowledge, such as Malachy Ó hĺomhair, as either one thing (e.g., a cleric) or another (e.g., a medic), but referred to them as 'hereditary men of learning', and it is considered this is the most relevant description of the Mac Caisín family who became medics of Osraí in the sixteenth century. But the reference to Mac Caisín being of Osraí is only accurate regarding their first recorded presence there in 1566. Aodh Mac Caisín, a medic, is found recorded in a manuscript probably dating to the fifteenth century (Ó Muráile, 2016), but there is no certainty Aodh was 'of Osrai'. Confidence, however, does come that Mac Caisín medics were out of a learnèd lineage not of Osrai'. In the fifteenth century, they can be found nearby, in the diocese of Cill Dalua - they are not referred to as medics, but as clerics.

Gwynn and Gleeson (1962) refer to key medieval monastic sites as centres of 'the tradition of learning in the fifteenth century', and they state that one such site was the Augustinian priory at Lothra (Lorrha) in the diocese of Cill Dalua. There are few surviving records of the provision of prebends of Lothra. Still, papal records inform several fifteenth-century associations of Mac Caisín clerics of Cilla Dalua, and they are all confined to a small area in the northwest of the diocese near Lothra, which is sometimes also called Dura (Dorrha). The earliest recorded Mac Caisín clerics of Cill Dalua are Thomas, Donat, and William. Thomas held the parish church of Dura, five miles east of the priory of Lothra, which he resigned ca. 1399. Donat, perhaps Thomas' son since he required dispensation for being the son of a cleric and an unmarried woman, was granted the Dura parish church prebend in 1400 subject to him being 'fit in Latin' (Bliss \& Twemlow, 1904a). William Mac Caisín, who was dispensed for the same defect, was promoted to hold the rectory of Dura in 1411, this after the death of Donat - William had previously held the rectory of Maigh Drithne (Modreeny), which is twelve miles south of Lothra (Bliss \& Twemlow, 1904b). William, who was unordained, died ca. 1421 (Twemlow, 1906), and Dura came to the possession of Cornelius Ó Cinnéide (Gleeson \& Costello, 1943). Another Donat Mac Caisín, likely the son of the previously mentioned Donat or William, probably succeeded Ó Cinnéide, but by 1437 he had been deprived of the parish church of Dura (Gleeson \& Costello, 1943). Nevertheless, Mac Caisín clerics continued to gain appointments around Lothra until the late fifteenth. In 1479, Maurice Mac Cashin succeeded to the Priory of Lothra - his annates were confirmed in Rome by his procurator, David de Burgh - and by 1487, Donat Mac Caisín had followed Maurice as prior (Gleeson \& Costello, 1943; Haren, 1978). The last appearance of a Mac Caisín cleric in the Papal registers comes in 1492, when prior Donat ruled in favour of William de Geraldinis concerning the abbacy of Monasteranenagh (Manister), in the diocese of Luimneach (Limerick) (Fuller, 1986).

There are several points of intrigue that are woven amongst the careers of the Mac Caisín hereditary clerics, but it is only as one critically explores all individuals, the monastic centres they issued from, and the clerical lineages they represented, that factors behind Mac Caisín relationships with the execution of papal mandates come to light. It should be recalled that the 'holding of well-endowed benefices by clerics of aristocratic lineages' was part and parcel of maintaining wealth, as well as having political influence, and this is best exemplified via the 'modus operandi' of various Augustinian clerical lineages and their wider kin networks 
during the fifteenth century (Mclnerney, 2014). It is an era when clerical appointments need to be understood in the context 'of the increasing domination of episcopal sees by members of powerful lineages' (MacCotter, 2016a). Those lineages were most obviously identified when men of the same surname secured benefice by succession. And, despite the Church's clear disapproval of such nepotism, there are numerous records of direct hereditary succession in plain view, which can be extracted from the Papal Registers. The works of Gwynn and Gleeson (1962), MacCotter (2016b), and Mclnerney (2014) provide more than ample discourse on the topic of clerical lineages, and the latter, in particular, explains that to avoid Rome's displeasure, hereditary succession needed to be inconspicuous.

Hence, strategies were often employed to mask paternal identities, and one such strategy was the use of alias surnames. What chance is there, then, for researchers some sixhundred plus years later, so used to categorising patrilineal relationships based solely on a single surname, and any 'irregularities' as non-paternity events, to be able to make sense of the familial connections the Papal Registers point to, yet do not lay bare? Without the sophistication of twenty-first-century science, it is considered there would be zero chance, but the insights that come with next-generation sequencing of the $Y$-chromosome can afford the construction of Y-DNA haplotrees of the descendants of clerics. That some highranking clerics were prolific is without a doubt (MacCotter, 2016b). So it becomes a question of not if their descendants can be found by Y-DNA analysis, but what are the modern surnames of those descendants, and how might those 'masked' surname lineages have arisen? (Fitzpatrick, 2021). It has been mooted that Costigans, FitzGeralds, and Fitzpatricks under haplotype R-A1488 may descend from a line of FitzMaurice of Ciarraí (Kerry) clerics, who may not only have spawned Mac Giolla Phádraig clerical lineages but Purcell and O'Hennessey clerical lines as well (Fitzpatrick, 2021). And could this be merely the tip of the iceberg - could the network of clerical lines be much more extensive? Indeed, there is evidence of associations between the Mac Caisín clerics and other clerical lineages that hints at a vast web of Augustinian familial connectivity.

There is 'no extant genealogy of the Uí Chaisín' (N. Ó Muráile, pers.comm., 21 October 2021), but it is the identification of northwest Cill Dalua as the centre where Mac Caisín clerics flourished from the fourteenth century that, ultimately, leads to an understanding of how, when and why they made their way into Osraí. And northwest Cill Dalua elsewise intrigues because the Papal Registers record, in 1488, that the benefice of the rectory of Tuain Uí Mheára (Toomyvara) was illegally detained by Rory Mac Costagáin (Haren, 1978). The Mac Costagáin will feature in a forthcoming article relating to their appearance in the fiants and patents, and reference will also be made to their clerics and their land proprietorships (Costigan \& Fitzpatrick, in press). They were a family unrecorded in Osraí until the late fifteenth century and appear only to have arisen there in the era contemporaneous with the rise to prominence of Mac Giolla Phádraig. And it is the record of John Mac Costagáin in 1481, remarkably revealed as 'alias Mac Giolla Phádraig' (Tremlow, 1955; Fitzpatrick, 2020a; Fitzpatrick, 2020b), which provides further basis for understanding the origins of the Mac Giolla Phádraig Osraí in the sixteenth century. Central are the relationships between the Augustinian houses of northwest Cill Dalua and the Augustinian houses of Osraí, most notably between the established centre of learning at

(C) Copyright 2020-21 | All rights reserved | The Fitzpatrick Clan Society

Fitzpatrick, M (2021) Pátraic surnames in the Fiants and Patent Rolls of Ireland: Part 1: a method of approach to mega-data, and a Mac Caisín case study. The Journal of the Fitzpatrick Clan Society 2, 66-92. 
Lothra and, thirty-five miles to the southwest, the priory of Achadh Mhic Art (Aghmacart), which from the early sixteenth century was on the rise.

\section{The priory of Achadh Mhic Art}

That there was a priory at Achadh Mhic Art from ancient times, i.e., ca. $550 \mathrm{AD}$, is without question based on oral tradition and archeological investigations (Archdall, 1786; Courtney, 2020). Although questions do surround the priory's re-establishment toward the end of the High Middle Ages (Carrigan, 1905), there is little reason to challenge the belief that Hugh Ó Díomasaigh founded the Augustinian priory at Achadh Mhic Art in the late twelfth or early thirteenth century. Such a timeframe is consistent with the date range attributed to the charter of the Abbey of Rosglas at Mainistir Eimhín (Monasterevin) ca. 1178-1189, which was definitively founded by Diarmaid Ó Díomasaigh, King of Uí Failghe, the father of Hugh (Alemand, Lucas \& Lamb, 1690; Mathews, 1903). Achadh Mhic Art is barely thirty miles southwest of Mainistir Eimhín, and the kingdom of the Uí Díomasaigh, at times, included swathes of lands in Laois. Although O'Donovan (1838) considered it unlikely the Augustinian priory was founded by the Uí Díomasaigh, stating, instead, that it was 'more probable Mac Giolla Patrick, Lord of Ossory, not O'Dempsey was the founder', this position appears based on the misguided assumption that Mac Giolla Phádraig held some sway in the north of Osraí in the late twelfth century. But there is no record of any Mac Giolla Phádraig association with Achadh Mhic Art until the fifteenth century.

A Norman presence is evidenced in the area from ca. 1210 (Curtis, 1923; Archdall, 1786), and in 1251 the prior and canons at Achadh Mhic Art, along with those at Feartach (Fertagh), obtained protection 'without term' from Henry III (Lyte, 1901). Any Irish presence at Achadh Mhic Art at this time appears to have been with the Uí Caollaidhe (O'Kelly).

Despite the thirteenth-century intrusions in the region by the de Hereford family, the native clan maintained a presence - the Justiciary Rolls of Edward I of England record that, in 1302, an Englishman called Richard de Blake had an Irish manservant of the 'family of Okegle of the parts of Adhmacart' (Mills, 1905). The priory at Achadh Mhic Art suffered heavily during the conflicts in the area during the early fourteenth century; this evidenced by the inability of the prior to pay taxes due the Bishop of Ossory ca. 1303-1306 (Lawlor, 1908). But regardless of the ongoing internecine struggle in the area in that era, Achadh Mhic Art was still subject to scutage due to Norman overlords in 1419 (Curtis, 1935). Then follow excellent accounts of various associations with the priory at Achadh Mhic Art, found in the Papal Registers, for the remainder of the fifteenth and into the sixteenth centuries - too voluminous for detailed discussion in this article, but summarised up until the end of the sixteenth century, as follows.

Priors of Achadh Mhic Art are not identified by name until the mid-fifteenth century, from when Uí Bróithe clerics dominated the position. An unusual sequence of events recorded in the Papal Registers, which involved Carolus the first named Uí Bróithe prior of Achadh Mhic Art, is recounted by Gywnn and Gleeson (1962). They picked up their narrative in 1414 when Dermot Ó Meadhra was appointed to the Augustinian priory of Móin na hlnse (Monaincha), one mile east of Ros Cré (Roscrea) town, and fifteen miles northwest of Achadh Mhic Art. The Uí Meadhra 'retained control of ...[ Móin na hlnse]... at all times up to 
the dissolution' (Gywnn \& Gleeson, 1962), although not without controversy. In 1450 the prior, another Dermot Ó Meadhra, stood accused of keeping a 'convent of concubines' and living 'a secular and unlawful life' - his accuser being unable to 'remain with a good conscience and peace of mind in the said monastery, wherein he made his regular profession', sought transfer to a canonry in Ros Comáin (Roscommon) (Twemlow, 1915, p.465).

This was no isolated incident, and it is apparent Móin na hlnse had become dilapidated by the same Augustinian excesses of this era, as documented elsewhere in the diocese of Cilla Dalua, as well as in the dioceses of Ail Finn (Elphin), Luimneach, and Port Láirge (Waterford) (Twemlow, 1906; Twemlow, 1909; Twemlow, 1915; Nicholls, 1969). The suggestion that some among the higher-ranking Augustinian clerics kept harems of nuns, securing 'access to a supply of women to provide heirs who would sustain their clerical lines' (Fitzpatrick, 2021), as well as providing 'dozens of infant offspring [who] might be fostered out to cement relations of clientage and political alliance' (Parkes, 2006, p.382) is not far-fetched; it merely echoes the practices of some of the medieval Irish dynasts the clerics sought to emulate. For example, 'Turlough an fhíona Ó Donnell, lord of Tirconnell (d. 1423) had eighteen sons (by ten different women) and fifty-nine grandsons in the male line' (Nicholls, 1972). But back to the affairs of Móin na hlnse; mandates from Rome ensued. In 1454 Carolus Ó Bróithe exchanged the priory of Achadh Mhic Art for Móin na hlnse; travelling in the opposite direction was Dermot Ó Meadhra, who is noted then as being the son of an OSA (Order of St Augustine) canon and an unmarried woman (Twemlow, 1915). The exchange was brief, and in 1455 it is evident that Carolus had died; his son, Patrick Ó Bróithe, was appointed to the priory of Achadh Mhic Art. Meanwhile, Dermot Ó Meadhra returned to Móin na hlnse. (Twemlow, 1915; Gwynn \& Glesson, 1962).

At this juncture, there are several threads that can be pursued in more detail. The renowned Osraí cleric, William Mac Giolla Phádraig, was born ca. 1444, being 'the son of an unmarried man and a ravished unmarried woman, related in the third degree of kindred' (Twemlow, 1960, p.83). William requires mention because assigning him a Mac Giolla Phádraig paternity is complex; his father was probably a cleric, but there are no obvious Mac Giolla Phádraig prospects (Fitzpatrick, 2020a). Yet, within the inventory of those local clerics who might be in the 'ravishing business', and with 'identity masking' being commonplace, Dermot Ó Meadhra must be among the frontrunners in William's fatherhood stakes. Does twenty-first-century science provide any evidence in support of William's paternity being with Dermot Ó Meadhra?

No small number of 'coincidences' and 'curiosities' appear in the surname matches under haplotype R-A1499, among whom are the likely descendants of Mac Giolla Phádraig Osraí clerics, who are haplotype R-A1488. The 'curious' surnames are Purcell, Hennessey, FitzGerald, and Costigan, which are found under various R-A1499 sub-haplotypes and easily lost among the 'noise' of Fitzpatrick DNA participants - they are curious because they are irrefutably associated with powerful clerics (Fitzpatrick 2021). To date, largely unnoticed, is also the surname O'Meara, which inhabits haplotype R-FT206758 along with four Fitzpatricks and one Costigan. The Uí Meadhra clerics were a powerful force in late medieval Cilla Dalua, and from 1354 they played a 'very prominent part in Ormond history' (Gwynn \& 
Gleeson, 1962). Medical lineages grew from them, and Oxford-educated Dr Dermot O'Meara was 'physician to the tenth Earl of Ormond', yet early origins of the Uí Meadhra are 'somewhat obscured' (O'Meara, 1996). However, Y-DNA is able to reveal what may be another example of 'surname masking'; the 'coincidence' and 'curiosity' of an Ó Meadhra under R-A1488 will enjoy further discussion in the forthcoming article, Mac Giolla Phádraig Clerics 1394-1534 AD, Part III.

Returning to Achadh Mhic Art, after Patrick Ó Bróithe's death the priory was, in 1466, granted to James Ó Bróithe, who was probably a son of either Carolus or Patrick since he was the son of a priest (Twemlow, 1933). In 1481 the priory was with William Ó Bróithe (Clohosey, 1957), confirmed by Rome in 1493 (Fuller, 1998), who made several notable judgments during his term: in 1485, in favour of William Mac Giolla Phádraig (Twemlow, 1960, Haren, 1978); in 1489 in favour of Patrick Mac Giolla Phádraig (Twemlow, 1960); in 1491, against Patrick Ó Duigan (Haren, 1978); in 1491, against Walter Ó Duigan (Haren, 1978); in 1493, in favour of Patrick Mac Giolla Phádraig on three occasions (Twemlow, 1960; Fuller, 1986); in 1493, in favour of Donat Mac Giolla Phádraig (Fuller, 1986); in 1493 in favour of John Mac Costagáin, alias John Mac Giolla Phádraig (Fuller, 1998). William Ó Bróithe's term as prior came under threat in 1498, when the twenty-three-year-old William Mac Giolla Phádraig, son of the aforementioned and powerful cleric of the same name, made his move to oust him (Fuller, 1986). Mac Giolla Phádraig contended that Ó Bróithe had held the priory without title, doubtless aware that it had taken Rome twelve years to rubber-stamp his appointment. The ambitious young cleric also argued that the priory could be united with the rectory of Domhnach Mór (Donaghmore), which was detained without right by William Ó Duigan - there can be no doubt that Mac Giolla Phádraig's coup attempt defines a watershed moment. The Mac Giolla Phádraig clerics had bided their time, grown in power, and then, in one swift move, launched an offensive against both the Uí Duigan and Uí Bróithe clerical houses.

The coup failed, but in 1508 William Ó Bróithe died - his successor, Patrick Ó Bróithe, detained the priory for 'certain months, short of a year', but he could not resist the now inevitable transfer of power, that mandate executed via the judgment of John Mac Costagáin, alias Mac Giolla Phádraig (Haren, 1998). And who else could have been appointed prior of Achadh Mhic Art, other than William, of the Costagáin-Mac Giolla Phádraig clerical line, who had nurtured been for the very role - William remained prior of Achadh Mhic Art until at least 1525 (Mac Quarrie, 2018). When trawling through the fifteenth and sixteenth-century records of the diocese of Osraí is easy to become lost in church politics, which was seemingly inseparable from the ambitions and quests for power by Norman houses and Irish clans alike. Yet, against this backdrop, it is likely the two most powerful Mac Giolla Phádraig clerics, William and son, were primarily responsible for the rise of the centre of learning at Achadh Mhic Art.

\section{The Medical School of Achadh Mhic Art}

The definitive review of the Medical School of Achadh Mhic Art is with Nic Dhonnchadha (2006), who states it was 'almost certainly long-established by 1500'; the basis Nic Dhonnchadha's statement of origination is the weakest part of her remarkable article since 
she provides none. However, if the foundation of the medical school at Achadh Mhic Art is viewed within the context of Mac Giolla Phádraig succession to the priory, it is more reasonable to place the date for that foundation close to 1508 than it is 'long' before 1500 . The root of Nic Dhonnchadha's (2006) date estimate is based solely on the 'approximate date of writing of the earliest document associated with it', but it is considered the production of medical texts would surely be a high priority for a new medical school, and one of the first tasks undertaken, not one left for a long period of time.

The attraction Achadh Mhic Art wielded under the benefactorship and leadership of the Mac Giolla Phádraig Osraí was great, and its reputation became established across Europe (Nic Dhonnchadha, 2006). The 'chief physician of Ossory', domiciled at Achadh Mhic Art, came to be known as 'the best of the doctors of Ireland in his own time', yet that physician was not a Mac Caisín, it was Donnchadh Óg Ó Conchubhair (Walsh, 1922). Indeed, the Uí Conchubhair were associated with the medical school of Achadh Mhic Airt for over one hundred years. The patriarch of the Uí Conchubhair of Osraí medics was Giolla Phádraig, who was related to the Mac Giolla Phádraig Osraí by marriage. Giolla Phádraig was active from ca. 1500, and his grandson, Donnchadh Óg Ó Conchubhair, was present when Barnaby Fitzpatrick, second Baron, made his last will and testament in 1581 - Carrigan (1905) mistakenly referred to Donnchadh Óg as a member of the Uí Caisín family. Donnchadh Óg was the personal physician of Florence Fitzpatrick, the third Baron, and a close associate of John Fitzpatrick, Florence's brother (Hare, 1978; Walsh, 1922; Nic Dhonnchadha, 2006).

Donnchadh Óg Ó Conchubhair's position as head medic did not sit well with the Mac Caisín, and it is clear the latter were not all high-brow academic types. In 1596, medic and scribe Donnchadh Albanach Ó Conchubhair, while staying at the Achadh Mhic Airt medical school, transcribed a section of 'Lilium medicine' under some duress, him being 'afraid of some of the race of Cashin who were among the outlaw band' (Walsh, 1922). The aggression of the Mac Caisín, and the fear Uí Conchubhair medics felt, was due to the Mac Caisín desiring the prestige and benefits of the ultimate position of medical service to the Mac Giolla Phádraig Osraí. In 1596, Niall Mac lomhair, a Scottish medical student at Achadh Mhic Art, noted 'the kindred of Caisín were striving' with Donnchadh Óg Ó Conchubhair to be the Chief Master of Medicine of Mac Giolla Phádraig (Bannerman, 1986). Niall considered this unjustified because 'the Mac Caisins were insufficiently skilled to be appointed to such a position' (Nic Dhonnchadha, 2000). It is considered the Uí Conchubhair medics 'ended their days in Upper Ossory' (Nic Dhonnchadha, 2006), but neither the Down Survey nor the 1659 'Census' record they acquired lands there.

\section{Conclusions, and a looking forward}

The fact there was no small number of Mac Caisín medics to the Mac Giolla Phádraig during the sixteenth century, and that their land proprietorship in Osraí was also significant during this period, provides some later context around why Morogh, Thomas, and John Mac Caisín had status in 1566, as fiant 897 appears to indicate. While they were esteemed, the Mac Caisín did not attain the same lofty heights as medics as did their Uí Conchubhair counterparts. So, it intrigues that Conchubhar Ó Conchubhair, a brother of Donnchadh Óg, appears 'further down the list' than Morogh, Thomas, and John in fiant 897. Also, the Uí 
Conchubhair medics did not appear to attain land proprietorships in Osraí, which leads to a nagging question - is there more to the Mac Caisín medics' relationship with the Mac Giolla Phádraig of Osraí than meets the eye?

In a return to where the conversation started, who were the Mac Caisín? Neither the fiants, patents, nor any other record indicates the Mac Caisín of Osraí were a lineage from an individual called Caisín Mac Giolla Phádraig. And, authoritatively, there is

'no evidence of Caisín being used as a personal name by the Mac Giolla Phádraig family, and in Mac Fhir Bhisigh's Book of Genealogies, the personal name Caisin is extremely rare; there are only three instances - one, if not two, of which look(s) very dubious' (N. Ó Muráile, pers.comm., 21 October 2021).

Likewise, there is no evidence the Mac Caisín were a line out of fosterage, or Mac Giolla Phádraig 'in-laws', or any other type of kinship bond. But this article began with questions not contrived to secure answers in the affirmative.

The Mac Caisín were more than just a hereditary medical family; they were a hereditary clerical family or, more broadly, a hereditary learnèd family, whose origins were in Cill Dalua before they were in Osraí. Their appearance in Osraí as medics probably came before the first record of them as such in 1566; it is likely they arrived from Cilla Dalua around the time of the establishment of the medical school Achadh Mhic Airt, ca. 1500, which is consistent with the last record of a Mac Caisín cleric in Cill Dalua, in 1492. It is not implausible that the Mac Caisín were patrilineally connected with the Mac Giolla Phádraig Osraí. Still, the complexities and variabilities of surname use, being part and parcel of clerical lineages, means it is unlikely that any such relationship could be uncovered by conventual genealogy. There is also currently no evidence that might be provided via Y-DNA analysis for a Mac Caisín-Mac Giolla Phádraig relationship via a clerical line, but while records such as the fiants and patents are not subject to change, with genetic data, one never knows.

An appropriate way of closing this article is to introduce the next subjects in the series, among whom are the Mac Séartha and the Mac Fynin; after the Mac Caisín, a good place for continuing a discussion of alternative surname Mac Giolla Phádraig Osraí septs are these for straightforward reasons. Although some earlier Mac Giolla Phádraig Osraí septs, only recently identified, had adopted alternative surnames before the Mac Séartha, such as Clann Maeleachlainn Ruadh (Fitzpatrick, 2020b), the Mac Séartha were long ago identified by Carrigan (1905) in remarkable and now well-cited fashion (e.g., Mac Lysaght, 1991).

For the record, Carrigan (1905) noted that Irish speakers of Osraí in his day 'never mentioned' Fitzpatricks 'under any other name than that of MacShaerha, O'Shaerha, or O'Sheerrha' - remarkable because for Fitzpatricks to be not mentioned, not even once, among the Irish speakers of Osraí seems unfathomable, as does the concept that all Fitzpatrick became called Mac Séartha. Carrigan's unequivocal position does not stand the test of time, but his sojourn into alternative Mac Giolla Phádraig surnames does. 
As such, a sceptical reader of narratives such as this Mac Caisín introduction to the fiants and patents of Ireland, which result in major disruptions of traditional Fitzpatrick histories, is unlikely to feel too uncomfortable venturing a little outside their Carriganesque world. And such journeying needs only be to authoritative and accessible records, such as Linea Antiqua (O'Farrell, 1709) where there are pedigrees of the Mac Fynin, or Fynen alias Fitzpatrick, who descend from the 'Lords of Ossory'.

\section{Acknowledgement}

The author thanks Professor Nollaig Ó Muráile for his support and insights. 


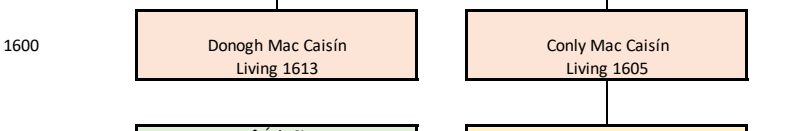

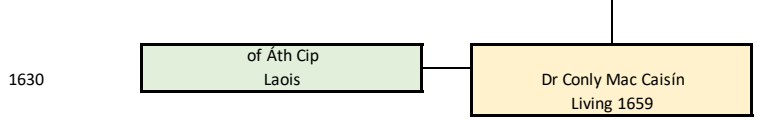

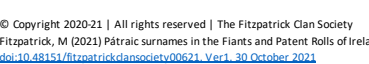

FIGURE 1: A POSSIBLE PEDIGREE OF MAC CAISÍN CLERICS \& MEDICS CA. 1399-1641

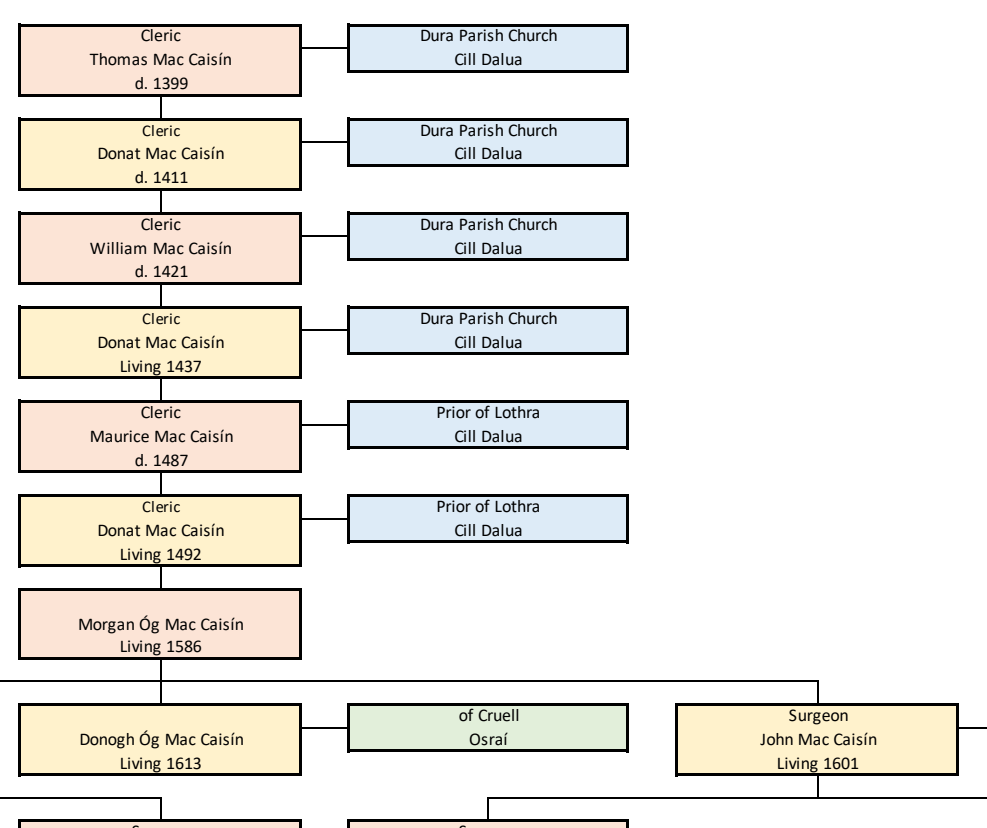




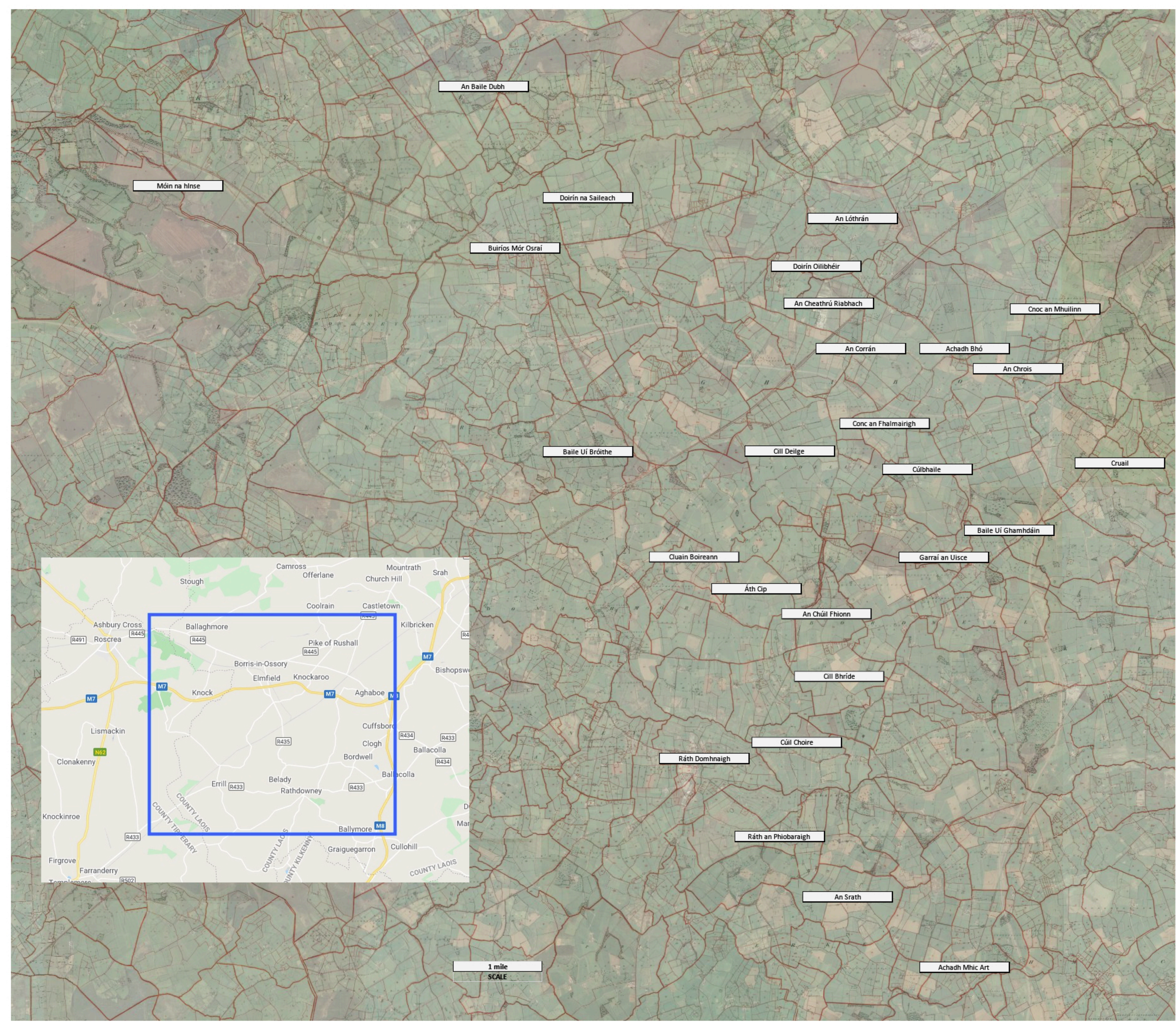

(c) Copyright 2020-21 | All rights reserved | The Fitzpatrick Clan Society

Fitzpatrick, M (2021) Pátraic surnames in the Fiants and Patent Rolls of Ireland: Part 1: a method of approach to mega-data, and a Mac

Caisín case study. The Journal of the Fitzpatrick Clan Society 2, 66-92.

doi:10.48151/fitzpatrickclansociety00621, Ver1, 30 October 2021
OS map imaged from Griffith's Valuation Ask About Ireland http://www.askaboutireland.ie/griffith-valuation

Accessed 27 October 2021

OMS Services Ltd, Eneclann Ltd and the National Library of Ireland 


\section{References}

1641 Depositions, Trinity College Dublin. https://1641.tcd.ie. Accessed 17 October 2021.

Alemand, L, Lucas, L and Lambin, A (1690). Histoire monastique d'Irlande, où l'on voit toutes les abbayes, prieurez, convens $\&$ autres communautez régulieres qu'il y a eu dans ce royaume... le nom des fondateurs, les villes... où elles étaient situés... avec quantité de remarques historiques et critiques. Paris: chez Louis Lucas.

Archdall, M. (1786). Monasticon Hibernicum: or, A history of the abbeys, priories, and other religious houses in Ireland; interspersed with memoirs of their several founders and benefactors, and of their abbots and other superiors, to the time of their final suppression. Dublin: WB Kelly.

Bacon, J (1642). A true relation of several overthrows given to the rebels. London: printed for Joseph Hunscot.

Bannerman, J (1986). The Beatons: A medical kindred in the classical Gaelic tradition. Edinburgh: John Donald Publishers.

Bliss, W and Twemlow, J (1902). Calendar of Papal Registers Relating To Great Britain and Ireland: Volume 4, 1362-1404. London, Public Record Office.

Bliss, W and Twemlow, J (1904a). Calendar of Papal Registers Relating To Great Britain and Ireland: Volume 5, 1398-1404. London, Public Record Office.

Bliss, W and Twemlow, J (1904b). Calendar of Papal Registers Relating To Great Britain and Ireland: Volume 6, 1404-1415. London, Public Record Office.

Carrigan, W (1905). The History and Antiquities of the Diocese of Ossory. Dublin: Sealy, Bryers and Walker.

Clarke, A (1967). Irish Patent Rolls of James I. Facsimile of the Irish Record Commission's Calendar. Dublin, Irish Manuscripts Commission.

Connolly, S (2011). The Oxford companion to Irish history. Oxford: Oxford University Press.

Cooke, T (1852) On ancient Irish bells. Transactions of the Kilkenny Archaeological Society 2, 47-63.

Cope, J (2009). England and the 1641 Irish Rebellion. Woodbridge, UK: Boydell Press.

Courtney, L (2020). Archaeological aerial survey - a bird's-eye view of the M7/M8 in County Laois. National Roads Authority, Transport Infrastructure, Ireland.

Curtis, E. (1923). A History of Medieval Ireland from 1110 to 1513. London: Macmillan.

Curtis, E (1932). Calendar of Ormond deeds Volume I. Dublin: The Stationery Office.

Curtis, E (1935). Calendar of Ormond deeds Volume III. Dublin: The Stationery Office.

Curtis, E (1941). Calendar of Ormond deeds Volume V. Dublin: The Stationery Office. 
Curtis, E (1970). Calendar of Ormond deeds Volume VI. Dublin: The Stationery Office.

Darcy, E (2015). The Irish rebellion of 1641 and the Wars of the Three Kingdoms. Woodbridge, Suffolk : The Boydell Press.

Darcy, E, Margey, A and Murphy, E (2016). The 1641 depositions and the Irish Rebellion. London : Routledge, 2016.

Down Survey (1641). Trinity College Dublin. http://downsurvey.tcd.ie. Accessed 21 October 2021.

Edwards, D (1993). The Butler Revolt of 1569. Irish Historical Studies, 28(111), 228-255.

Fewer, M. (2019). The battle of the Four Courts, 28-30 June 1922. History Ireland, 27, 44-47.

Fitzpatrick, E and Fitzpatrick, M (2020). When Everything Changes: Using Critical Family History to Deconstruct Keesing and Fitzpatrick Surnames. Genealogy, 4, 25.doi.org/10.3390/genealogy4010025

Fitzpatrick, M (2020a) Mac Giolla Phádraig Osraí 1384-1534 AD Part I. The Journal of the Fitzpatrick Clan Society 1, 1-17. doi:10.48151/fitzpatrickclansociety00120

Fitzpatrick, M (2020b) Mac Giolla Phádraig Osraí 1384-1534 AD Part II. The Journal of the Fitzpatrick Clan Society 1, 40-71. doi:10.48151/fitzpatrickclansociety00320

Fitzpatrick, M (2021) Mac Giolla Phádraig Clerics 1394-1534 AD, Part I. The Journal of the Fitzpatrick Clan Society 2, 42-65. doi:10.48151/fitzpatrickclansociety00521

Fitzpatrick, M and Fitzpatrick, I (2021) The similar-sounding surnames of haplotype R-BY140757. The Journal of the Fitzpatrick Clan Society 2, 1-41. doi:10.48151/fitzpatrickclansociety00421

Fuller, A (1986). Calendar of Papal Registers Relating To Great Britain and Ireland: Volume 16, 14951503. Dublin, Irish Manuscripts Commission.

Fuller, A (1998) Calendar of Papal Registers Relating To Great Britain and Ireland: Volume 17. Part II 1492-1503. Dublin, Irish Manuscripts Commission.

Gibney, J (2013). The shadow of a year: The 1641 rebellion in Irish history and memory. Madison: University of Wisconsin Press.

Gleeson, D (1949). The Coarbs of Killaloe Diocese. The Journal of the Royal Society of Antiquaries of Ireland, 79, 160-169.

Gleeson D and Costello M (1943). Obligationes pro Annatis Diocesis Laoniensis 1421-1535. Archivium Hibernicum, 10, 1-103.

Graham, H (1925). Irish Monks and the Transmission of Learning. The Catholic Historical Review, 11, 431-442.

Gwynn, A and Gleeson, D (1962). A history of the Diocese of Killaloe: Vol. 1: pt. I., pt. 2. Dublin: Gill.

(C) Copyright 2020-21 | All rights reserved | The Fitzpatrick Clan Society

Fitzpatrick, M (2021) Pátraic surnames in the Fiants and Patent Rolls of Ireland: Part 1: a method of approach to mega-data, and a Mac Caisín case study. The Journal of the Fitzpatrick Clan Society 2, 66-92.

doi:10.48151/fitzpatrickclansociety00621, Ver1, 30 October 2021 
Hamilton, H (1860). Calendar of the State Papers of Ireland, of the reigns of Henry VIII, Edward VI, Mary, and Elizabeth, 1509-1573. London: Longman, Green, Longman, and Roberts.

Haren, M (1978) Calendar of Papal Registers Relating To Great Britain and Ireland: Volume 15. 14841492. Dublin, Irish Manuscripts Commission.

Haren, M (1998) Calendar of Papal Registers Relating To Great Britain and Ireland: Volume 19. 15031513. Dublin, Irish Manuscripts Commission.

HMSO, (1875). The seventh report of the deputy keeper of the public records in Ireland. Dublin: Alexander Thom for Her Majesty's Printing Office.

HMSO, (1879). The eleventh report of the deputy keeper of the public records in Ireland. Dublin: Alexander Thom for Her Majesty's Printing Office.

HMSO, (1880). The twelfth report of the deputy keeper of the public records in Ireland. Dublin: Alexander Thom for Her Majesty's Printing Office.

HMSO, (1883). The fifteenth report of the deputy keeper of the public records in Ireland. Dublin: Alexander Thom for Her Majesty's Printing Office.

HMSO, (1884). The sixteenth report of the deputy keeper of the public records in Ireland. Dublin: Alexander Thom for Her Majesty's Printing Office.

HMSO, (1885). The seventeenth report of the deputy keeper of the public records in Ireland. Dublin: Alexander Thom for Her Majesty's Printing Office.

Inquisitionum in officio rotulorum cancellariae Hiberniae asservatarum, repertorium, volume I (1826). Erscheinungsort nicht ermittelbar.

Lawlor, H (1908). Calendar of the Liber Ruber of the Diocese of Ossory. Proceedings of the Royal Irish Academy. Section C: Archaeology, Celtic Studies, History, Linguistics, Literature 27, 159-208.

Lyte, H (1901). Calendar of Patent Rolls, Henry III: Volume 1, 1216-1225. London, His Majesty's Stationery Office.

MacCotter, P. (2004). The Geraldine clerical lineages of Imokilly and Sir John fitz Edmund of Cloyne. D. Edwards (ed), Regions and Rulers in Ireland, 1100-1650, 54-77. Dublin, Four Courts Press.

MacCotter, P. (2016a). Journal of the Kerry Archaeological and Historical Society, 16, 5-35.

MacCotter, P. (2016b). The dynastic ramifications of the Geraldines. P. Crooks and S. Duffy (eds), The Geraldines and Medieval Ireland. Dublin, Four Courts Press.

Mac Lysaght, E (1985). Irish Families: Their Names, Arms and Origins. Dublin, Irish Academic Press.

Mac Lysaght, E. (1991). The surnames of Ireland. Dublin, Ireland: Irish Academic Press.

Mac Niocaill, G (1992). Crown surveys of lands, 1540-41: with the Kildare rental begun in 1518. Dublin: Irish Manuscripts Commission, pp.443

(C) Copyright 2020-21 | All rights reserved | The Fitzpatrick Clan Society

Fitzpatrick, M (2021) Pátraic surnames in the Fiants and Patent Rolls of Ireland: Part 1: a method of approach to mega-data, and a Mac Caisín case study. The Journal of the Fitzpatrick Clan Society 2, 66-92.

doi:10.48151/fitzpatrickclansociety00621, Ver1, 30 October 2021 
Mac Quarrie A (2018). Calendar of Papal Registers Relating To Great Britain and Ireland: Volume 23, Part I 1523-1534. Dublin, Irish Manuscripts Commission.

McInerney, L. (2014). Clerical and learned lineages of medieval Co. Clare: A survey of the fifteenthcentury papal registers. Dublin, Four Courts Press.

Morgan, H (1993). Tyrone's rebellion: The outbreak of the Nine Years War in Tudor Ireland. Rochester: The Boydell press.

Mathews, T (1903). The O’Dempseys of Clan Maliere. Dublin: Hodges, Figgis \& Co. Ltd.

Mills, J (1905). Calendar of the Justiciary Rolls: Or, Proceedings in the Court of the Justiciar of Ireland preserved in the Public record office of Ireland. Dublin, His Majesty's Stationery Office.

Morrin, J (1861). Calendar of the patent and close rolls of Chancery in Ireland, of the reign of Charles I, first to eighth year inclusive . Dublin: Alexander Thom for Her Majesty's Stationery Office.

Morrin, J (1863). Calendar of the patent and close rolls of Chancery in Ireland, of the reigns of Henry VIII., Edward VI., Mary, and Elizabeth. Dublin: Alexander Thom for Her Majesty's Stationery Office.

Nelligan, T and Dempsey G (2020). Picking up the pieces. Archaeology Ireland 34, 23-26.

Nic Dhonnchadha, A (2000). Medical writing in Irish. Irish Journal of Medical Science 169, 217-220.

Nic Dhonnchadha, A (2006). The Medical school of Aghmacart Queen County. Ossory, Laois and Leinster, 2, 11-43.

Nicholls, K. (1970). The FitzMaurices of Kerry. Journal of the Kerry Archaeological and Historical Society, 3, 23-42.

Nicholls, K (1972). Gaelic and Gaelicized Ireland in the Middle Ages. Dublin: Lilliput.

O'Donovan J (1838). Ordinance survey of Ireland: Letters, Queen's County (Laois). Dublin: Ordinance Survey Office.

O'Ferrall, R. (1709). Linea Antiqua, a collection of Irish genealogies compiled by Roger O'Ferrall, with index. Genealogical Office Manuscripts Collection MS 155.

O'Meara, K. (1996). O'Meara family origins, [dissertation], Trinity College, Dublin, Ireland.

Department of History, pp 10.

Ó Muraíle, N (2016): The hereditary medical families of Gaelic Ireland. in: Ó Murchú, L [ed.], Rosa Anglica: reassessments, Irish Texts Society, Subsidiary Series 28, London: Irish Texts Society, 85-113

Parkes, P (2006). Celtic Fosterage: Adoptive Kinship and Clientage in Northwest Europe. Comparative Studies in Society and History, 48, 359-395.

Price, L (1933). The Byrnes' Country in County Wicklow in the Sixteenth Century. The Journal of the Royal Society of Antiquaries of Ireland, 3, 224-242.

C) Copyright 2020-21 | All rights reserved I The Fitzpatrick Clan Society

Fitzpatrick, M (2021) Pátraic surnames in the Fiants and Patent Rolls of Ireland: Part 1: a method of approach to mega-data, and a Mac Caisín case study. The Journal of the Fitzpatrick Clan Society 2, 66-92.

doi:10.48151/fitzpatrickclansociety00621, Ver1, 30 October 2021 
Rowe, J (1916). Rory Oge O’More: The First of the Rapparees. The Irish Monthly, 44, 613-626.

Shearman, J. (1879). Loca Patriciana: An Identification of Localities, Chiefly in Leinster, Visited by Saint Patrick and His Assistant Missionaries and of Some Contemporary Kings and Chieftains. Dublin: M. H. Gill.

State papers (1834): King Henry the Eighth Volume III. London: Eyre.

Twemlow, J. (1906). Calendar of Papal Registers Relating To Great Britain and Ireland: Volume 7, 1417-1431. London, His Majesty's Printing Office.

Twemlow, J. (1909). Calendar of Papal Registers Relating To Great Britain and Ireland: Volume 8, 1427-1447. London, His Majesty's Printing Office.

Twemlow, J. (1915). Calendar of Papal Registers Relating To Great Britain and Ireland: Volume 10, 1447-1455. London, His Majesty's Printing Office.

Twemlow, J. (1933). Calendar of Papal Registers Relating To Great Britain and Ireland: Volume 12, 1458-1471. London, His Majesty's Printing Office.

Twemlow, J. (1955). Calendar of Papal Registers Relating To Great Britain and Ireland: Volume 13, 1471-1484. London, Her Majesty's Printing Office.

Twemlow, J. (1960). Calendar of Papal Registers Relating To Great Britain and Ireland: Volume 14, 1484-1492. London, Her Majesty's Printing Office.

Walsh, P (1922). Gleanings from Irish MSS. Dublin: At the Sign of the Three Candles.

Woulfe, P. (1923). Sloinnte Gaedheal Is Gall: Irish Names and Surnames. Dublin: M. H. Gill \& Son. 